\title{
About a Portuguese communiti's awareness of antibiotic use
}

\section{Acerca dos conhecimentos de uma comunidade Portuguesa no consumo de antibióticos}

\author{
Cristiana Matos, Inês Nunes da Cunha \\ CBIOS - Universidade Lusófona's Research Center for Biosciences and Health Technologies, Campo Grande 376 , \\ 1749-024, Lisboa, Portugal \\ Farmácia Campos Gomes, Rua D. Manuel II, 57, 2560-016, A-dos-Cunhados, Torres Vedras \\ Email: matoscristiana@hotmail.com
}

\begin{abstract}
Antibiotics are used in the treatment of infections with the purpose of eliminating or preventing the bacterial growth. Over the years, bacteria has become resistant to antibiotics due to incorrect use and overuse.

The aim of this cross-sectional study was to assess the pharmacy users' awareness of antibiotic use. This was done in order to identify potential inaccuracies during treatment, as well as to evaluate the respondents' awareness of bacterial resistance as a public health problem. The questionnaire was applied to users in the form of interviews which took place during the period May to July 2012.

This study involved 106 individuals aged over 16 years. The treatment of throat infections was the main reason given for the consumption of antibiotics (22.6\%). $64.2 \%$ of the respondents believed that bacteria often cause colds and flu, and $30.2 \%$ of the respondents said that they did not complete the treatment. $81.1 \%$ of respondents recognized the existence of the problem of bacterial resistance to antibiotics. Statistical analysis indicated a significant difference between age group $(p$-value $=0.001)$ and educational qualifications $(p$-value $=0.004)$ related to the knowledge of the type of infections treated with antibiotics. Knowledge regarding the mode of consumption of antibiotics in small geographic areas allows local health professionals to improve the way antibiotics are used.
\end{abstract}

Keywords: antibiotics, bacterial drug resistance, knowledge of patients, bacterial infection

\section{Resumo}

Os antibióticos são utilizados no tratamento de infecções com a finalidade de eliminar ou impedir o crescimento bacteriano. Ao longo dos anos, as bactérias tornaram-se resistentes aos antibióticos pelo seu uso abusivo e incorrecto.

Este estudo descritivo transversal foi realizado com os objectivos de avaliar o conhecimento dos utentes de uma farmácia no consumo de antibióticos, identificar possíveis incorrecções durante o tratamento e avaliar a consciência dos inquiridos relativamente à resistência bacteriana como um problema de saúde pública. Foi aplicado um inquérito aos utentes, na forma de entrevista, durante Maio a Julho de 2012.

Participaram no estudo 106 indivíduos com idade superior a 16 anos. O tratamento de infecções da garganta foi a principal razão apontada para o consumo de antibióticos (22,6 \%). Dos inquiridos, 64,2 \% acreditava que as bactérias causam frequentemente gripes e constipações e 30,2 \% afirmaram não completarem o tratamento. 81,1 $\%$ dos inquiridos reconheceram a existência da problemática de resistências bacterianas aos antibióticos. A análise estatística indicou diferença significativa entre as variáveis grupo etário $(p$-value $=0,001)$ e nível de escolaridade ( $\mathrm{p}$-value $=0,004)$ com a variável conhecimento do tipo de infecções combatidas pelos antibióticos.

A noção do modo de consumo dos antibióticos em pequenas áreas geográficas permite auxiliar os seus profissionais de saúde a intervirem no seu uso racional.

Palavras-chave: antibióticos, resistência bacteriana, conhecimentos dos utentes, infecção bacteriana 


\section{Introduction}

In 1936, the modern era of pharmacological treatment of infections began with the human clinical use of sul-

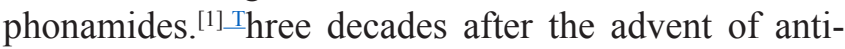
biotics, mean life expectancy increased by about eight years. ${ }^{[2]}$ It was believed that vaccination programs and disinfection procedures in conjunction with antibiotics, would end the threat of epidemics. ${ }^{[3]}$ Shortly thereafter, the use of antibiotics became widespread, far beyond human and animal treatment. ${ }^{[4]}$ The abuse in antibiotic consumption led to the current problem of bacterial resistance. ${ }^{[5]}$

The profile of bacterial resistance to antibiotics is very different in the varying regions of the globe. South eastern European countries have the highest antibiotics consumption rates, while the lowest occurs in the north of Europe and the Russian Federation. ${ }^{[6]}$.For many years, Portugal has been rated in the European ranking as one of the countries with the highest rate of antibiotics use, especially of broad-spectrum antibiotics._Baseline studies in Portugal have shown a tendency to antibiotics overuse in empirical indications, particularly in respiratory tract infections. ${ }^{[5]}$

Nowadays, there are several multi-resistant microorganisms which are not sensitive to any clinically available antibiotics and which can be quickly lethal to infected patients. ${ }^{[5]}$ According to the World Health Organization data, infections cause $25 \%$ of deaths worldwide and $45 \%$ in developing countries. ${ }^{[7]}$ The use of antibiotics in these situations has a calculated dimension. Over 50 $\%$ of prescriptions are inappropriate, in many countries $2 / 3$ of antibiotics are used without a clinical prescription, $50 \%$ of patients buy the antibiotic for one day and $90 \%$ buy for a period of three days or less. ${ }^{[5]} \mathrm{I} t \mathrm{t}$ is also estimated that one third of hospitalized patients take antibiotics and these drugs are unnecessary in approximately $50 \%$ of cases. ${ }^{[8]}$

Self-medication can select resistant strains within commensal flora and cause an infection by opportunistic bacteria, which is resistant to the antibiotic. ${ }^{[4]}$ Noncompliance of patients to proposed treatments is also frequent._Patients forget to take medications and interrupt the treatment soon after they feel better. These behaviors in the population create conditions for the microorganisms to adapt instead of being eliminated. ${ }^{[5]}$ In several studies, it was found that patients' knowledge about the correct use of antibiotics is limited. Patients believe that antibiotics treat colds and are effective against viruses, and some patients are unaware of antibiotics resistance. ${ }^{[9-13]}$

It is believed that the most significant impact strategies for containment of antibiotic resistance are the rational

\section{Introdução}

A era moderna do tratamento farmacológico das infecções iniciou-se em 1936 com a utilização clínica humana de sulfamidas. ${ }^{[1]}$ Nas três décadas após o aparecimento dos antibióticos, a esperança média de vida aumentou cerca de oito anos. ${ }^{[2]}$ Acreditou-se que os programas de vacinação e procedimentos de desinfecção, em conjunto com os antibióticos, acabariam definitivamente com a ameaça de epidemias ${ }^{[3]}$ Pouco tempo depois, a utilização dos antibióticos generalizou-se, muito além do tratamento humano e animal. ${ }^{[4]}$ Foi o abuso no consumo de antibióticos que conduziu à actual problemática da resistência bacteriana. ${ }^{[5]}$

O perfil da resistência bacteriana aos antibióticos é muito variável entre as regiões do globo. Os países do sul e leste da Europa apresentam o consumo mais elevado de antibióticos, enquanto o consumo mais baixo verificase no norte da Europa e Federação Russa. ${ }^{[6]}$ Portugal vem desde há anos cotado no ranking europeu como um dos primeiros países no consumo de antibióticos, particularmente antibióticos de amplo espectro. Estudos de referência em Portugal, mostram que existe uma tendência para o uso excessivo de antibióticos perante indicações clínicas empíricas, particularmente nas infecções do tracto respiratório. ${ }^{[5]}$

Actualmente conhecem-se microrganismos multirresistentes, não sensíveis a quaisquer dos antibióticos disponíveis clinicamente, que conduzem rapidamente à morte de doentes infectados. ${ }^{[5]}$ Segundo dados da Organização Mundial de Saúde, as infecções causam 25 $\%$ das mortes em todo o mundo e $45 \%$ nos países em desenvolvimento. ${ }^{[7]} \mathrm{O}$ uso de antibióticos para essas situações tem magnitude calculada, sendo que: mais de $50 \%$ das prescrições mostram-se inapropriadas, $2 / 3$ dos antibióticos são usados sem prescrição médica em muitos países, $50 \%$ dos doentes compram o antibiótico para um dia e $90 \%$ compram-no para um período igual ou inferior a 3 dias. ${ }^{[5]}$ Também se estima que um terço dos doentes hospitalizados toma antibióticos e que estes fármacos são desnecessários em aproximadamente 50 $\%$ dos casos. ${ }^{[8]}$

A automedicação pode seleccionar estirpes resistentes entre a flora comensal e originar uma infecção por uma bactéria oportunista, que eventualmente era resistente ao antibiótico. ${ }^{[4]}$ A não adesão dos doentes aos tratamentos propostos é também frequente. Os doentes esquecem-se de tomar os medicamentos e interrompemnos quando se sentem melhores. Estes comportamentos, recorrentes entre a população, criam condições para que os microrganismos se adaptem em vez de serem eliminados. ${ }^{[5]}$

Em vários estudos, foi verificado que o conhecimento dos doentes sobre o uso correcto de antibióticos é limitado, sendo que os doentes pensam que os antibióticos tratam constipações e são eficazes contra vírus, e alguns 
use of antibiotics and prevention of resistant strains transmission. ${ }^{[14,15]}$

In relation to this current problem, this study was conducted in order to assess the Pharmacy Campos Gomes users' knowledge of antibiotics consumption, to identify potential inaccuracies during treatment, as well as to evaluate respondents' awareness in relation to bacterial resistance as a public health problem. Furthermore, notion about antibiotics consumption mode in smaller geographic areas allows local health professionals to improve their daily use. By conducting intervention studies within these populations it is possible to disclose the current problem of bacterial resistance.

\section{Material and Methods}

A population-based cross-sectional study took place at the Pharmacy Campos Gomes between May and July of 2012. Data was collected in an interview guided by a questionnaire. The questionnaire's items were developed based on previous studies and related to the influence of users' knowledge of the consumption of antibiotics. ${ }^{[9,12,13,16-18]}$ Respondents were randomly selected during the 9:00 to $12: 00$ am period from Monday to Friday. Individuals under 16 years were not included, nor were individuals with cognitive disorders and communication difficulties. Regarding the size of the sample, it is known that larger sample dimensions offer more reliable results. It is considered that a sample of a least $1 \%$ of the population appears as a representative sample. ${ }^{[18]}$ In this study, the sample should consist of a minimum of 70 respondents of 6936 inhabitants of the parish served by this pharmacy (A-dos-Cunhados, Torres Vedras).

The questionnaire was structured in three parts with closed questions. The first part included socio-demographic characteristics (sex, age group and educational qualifications). The second part included consumption and attitudes questions regarding treatment with antibiotics. And the third part focused on issues related to the development of bacterial resistance to antibiotics.

Statistical data was analyzed using the software - SPSS 20.0 (Statistical Package for Social Sciences). Results were treated by descriptive statistics and statistical tests to analyze the relationship between the variables.

After the survey, each respondent was given a leaflet created by the authors which contained information about the issues addressed to provide further clarification. não têm conhecimento da existência de resistências aos antibióticos. ${ }^{[9-13]}$

Acredita-se que as estratégias com impacto mais significativo para a contenção da resistência aos antibióticos, são o uso racional dos antibióticos e a prevenção da transmissão de estirpes resistentes. ${ }^{[14,15]}$

Tendo em conta esta problemática, este estudo foi realizado com os objectivos de avaliar o conhecimento dos utentes da Farmácia Campos Gomes no consumo de antibióticos, identificar possíveis incorrecções durante o tratamento e avaliar a consciência dos inquiridos relativamente à resistência bacteriana como um problema de saúde pública. Além disso, a noção do modo de consumo de antibióticos em pequenas áreas geográficas permite auxiliar os seus profissionais de saúde a melhorarem a sua utilização diária. Deste modo, através da realização de estudos com intervenção das populações é possível divulgar a problemática actual da resistência bacteriana aos antibióticos.

\section{Material e Métodos}

Foi realizado um estudo transversal de base populacional na Farmácia Campos Gomes. Os dados foram recolhidos a partir de um questionário elaborado, tendo como referência estudos anteriores, onde foram considerados os factores que podiam influenciar os conhecimentos dos utentes no consumo de antibióticos. ${ }^{[9,12,13,16-18]}$ Posteriormente, o questionário foi aplicado aos utentes da farmácia, na forma de entrevista, durante os meses de Maio a Julho de 2012. Os inquiridos foram seleccionados ao acaso durante o período das 9:00 às 12:00 de segunda a sexta-feira, tendo sido excluídos indivíduos com idade inferior a 16 anos e com desordens cognitivas e dificuldade de comunicação. Relativamente à dimensão da amostra, e tendo em conta que quanto maior a amostra mais credíveis são os resultados, considera-se que uma amostra constituída pelo menos por $1 \%$ da população afigura-se como uma amostra representativa. ${ }^{[18]}$ Assim, neste estudo, a amostra deveria ser constituída por um mínimo de 70 inquiridos dos 6936 habitantes da freguesia onde a farmácia presta serviço (A-dosCunhados, Torres Vedras).

O questionário foi estruturado na forma de questões fechadas em três partes. A primeira incluiu questões sociodemográficas (sexo, grupo etário e nível de escolaridade). A segunda parte incluiu questões sobre o consumo e práticas no tratamento com antibióticos. E a terceira parte incidiu em questões relacionadas com o desenvolvimento de resistências bacterianas aos antibióticos.

O programa informático utilizado no tratamento dos dados foi o SPSS 20.0 (Statistical Package for Social Sciences). Recorreu-se à estatística descritiva e testes estatísticos para analisar a relação entre variáveis.

Após a realização do inquérito foi entregue a cada inquirido um folheto informativo construído pelos autores. Neste, constava informação explicativa sobre cada item do questionário, tendo como finalidade o esclarecimento dos tópicos questionados. 


\section{Results and Discussion}

106 individuals were interviewed in this study, including 72 females (67.9\%) and 34 males (32.1\%)._Respondents were older than 16 years old. The predominant age range was 66 years old and upwards (40.6\%) followed by the age groups $31-50$ years old $(32.1 \%)$ and 51-65 years old (19.8\%). The age range with the lowest representation was 16-18 years old (3.8\%) and 19-30 years old (3.8\%).

Figure 1 shows the educational qualifications of the sample. We observed that $36.8 \%$ of respondents had the lowest educational grade. $15.1 \%$ of respondents had no educational qualifications and $6.6 \%$ had a higher education.

\section{Resultados e Discussão}

Neste estudo, foram entrevistados 106 indivíduos, dos quais 72 do sexo feminino $(67,9 \%)$ e 34 do sexo masculino $(32,1 \%)$. Os inquiridos apresentavam idades superiores a 16 anos, predominando o intervalo de idades a partir dos 66 anos (40,6 \%) seguindo-se os grupos etários entre 31 e 50 anos de idade (32,1\%), e entre 51 e 65 anos $(19,8 \%)$. O intervalo de idades com menor representação foi o que varia entre os 16 e 18 anos (3,8 $\%)$ e entre os 19 e 30 anos $(3,8 \%)$.

A figura 1 mostra as habilitações literárias da amostra, verificando-se que $36,8 \%$ dos inquiridos possuíam o $1^{\circ}$ ciclo de escolaridade, $15,1 \%$ dos inquiridos não tinham

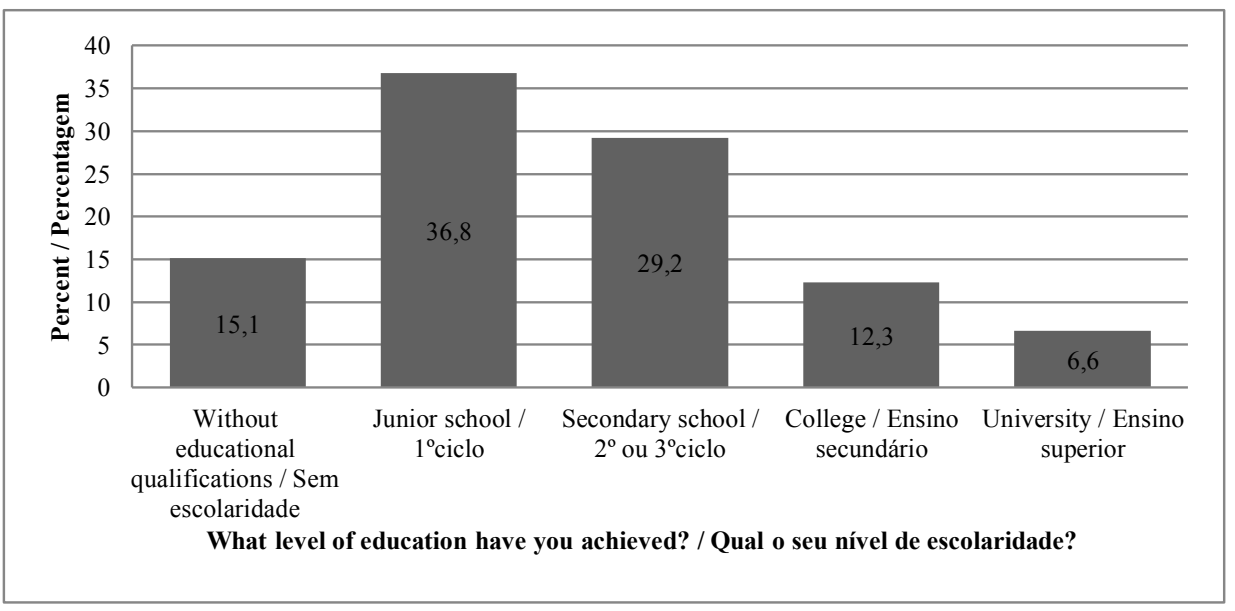

Figure 1 - Educational qualifications

Figura 1 - Habilitações literárias

Regarding the use of antibiotics, as shown in Figure 2, from the 106 respondents $67.9 \%$ had taken antibiotics more than ten times in their life and $32.1 \%$ reported to having taken antibiotics less than ten times. Thus, all respondents stated that they had taken antibiotics at least once in their life. $36.8 \%$ of respondents had taken antibiotics more than a year ago, and $35.8 \%$ had taken them this year (figure 3 ).

According to Figure 4, the most common reasons why the respondents took antibiotics were sore throat $(22.6$ $\%)$, flu (17\%), other reasons not described (17\%), urinary tract infection $(8.5 \%)$, skin infection $(7.6 \%)$, cold $(6.6 \%)$, pneumonia $(3.8 \%)$, diarrhea $(2.8 \%)$ and bronchitis $(2.8 \%)$. The choice of "other reason" included, for example, other respiratory infections, dental infections, post-surgery and ear infections._Furthermore, escolaridade, e 6,6 \% possuíam habilitações de ensino superior.

Relativamente ao consumo de antibióticos, como indica a figura 2, dos 106 inquiridos, 67,9\% tomaram antibiótico mais de dez vezes na sua vida e 32,1 \% afirmaram que tomaram antibiótico menos de dez vezes. Assim, verificou-se que todos os entrevistados afirmaram já ter tomado antibióticos pelo menos uma vez na vida. 36,8 \% dos inquiridos, tomaram antibiótico há mais de um ano e 35,8 \% tomaram no decorrente ano (figura 3).

De acordo com a figura 4, as razões mais frequentes que levaram os utentes a consumir antibióticos foram: garganta inflamada $(22,6 \%)$, gripe $(17 \%)$, outras razões não descritas $(17 \%)$, infecção urinária $(8,5 \%)$, infecção cutânea $(7,6 \%)$, constipação $(6,6 \%)$, pneumonia 


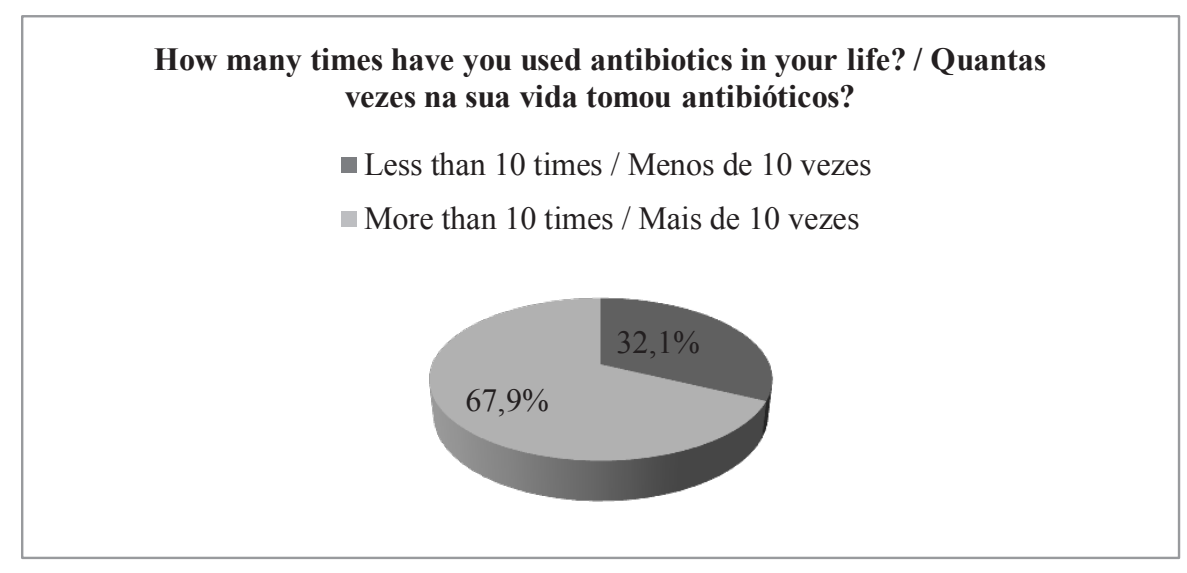

Figure 2 - Number of times the patients took antibiotics

Figura 2 - Número de vezes que os utentes tomaram antibiótico

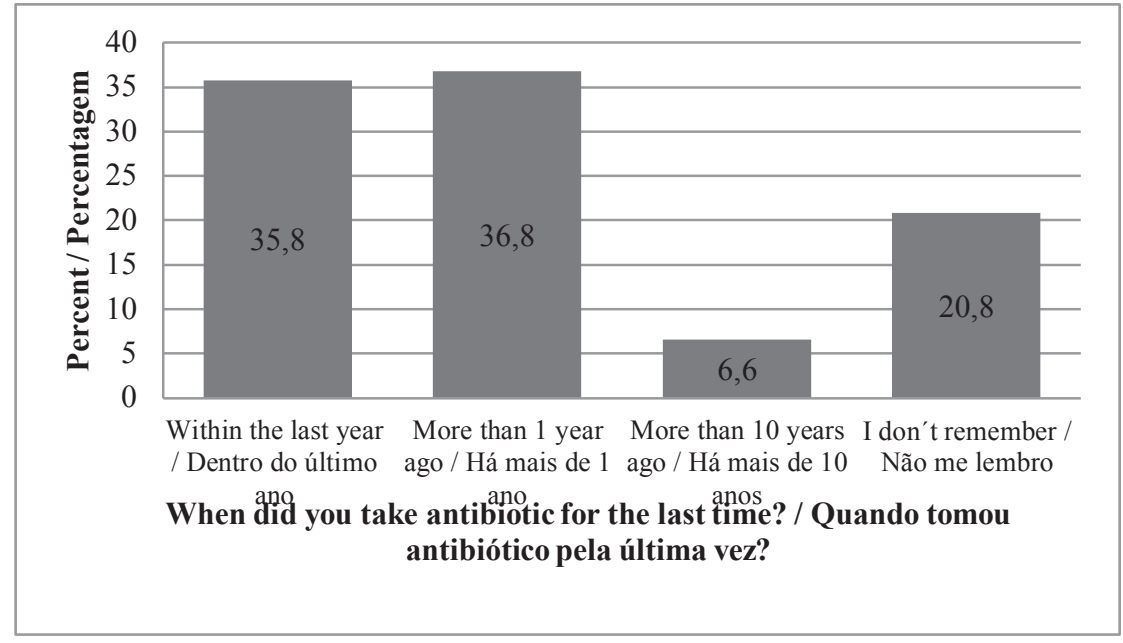

Figure 3 - Temporal frequency of the last time that the patients took antibiotic

Figura 3 - Frequência temporal da última vez que os utentes tomaram antibiótico

$11.3 \%$ of respondents could not remember the reason that led them to take antibiotics.

Figure 5 shows that $37.7 \%$ of respondents admitted to not knowing what type of infections were treated by antibiotics, while $22.6 \%$ reported that antibiotics are used for diseases caused by viruses and bacteria infections. Only $21.7 \%$ knew that antibiotics are used for treating bacterial infections.

According to Table 1, 64.2\% of respondents said that bacteria often cause colds and flu. Although a medical prescription is required for dispensing antibiotics, $13.2 \%$ of users admitted that they have tried to buy antibiotics without a prescription. With regard to the conduct of
$(3,8 \%)$, diarreia $(2,8 \%)$ e bronquite $(2,8 \%)$. Motivos que levaram à escolha da opção "outra razão" incluem, por exemplo, outro tipo de infecções respiratórias, infecções dentárias, pós-cirurgias e otites. Além disso, $11,3 \%$ dos inquiridos não se lembravam da razão que os levou a tomar antibiótico.

A figura 5 mostra que $37,7 \%$ dos inquiridos admitiu não saber qual o tipo de infecções combatidas pelos antibióticos, enquanto $22,6 \%$ dos indivíduos afirmaram que os antibióticos combatem infecções provocadas por vírus e bactérias. Apenas 21,7 \% afirmaram que os antibióticos são usados para o tratamento de infecções bacterianas. 


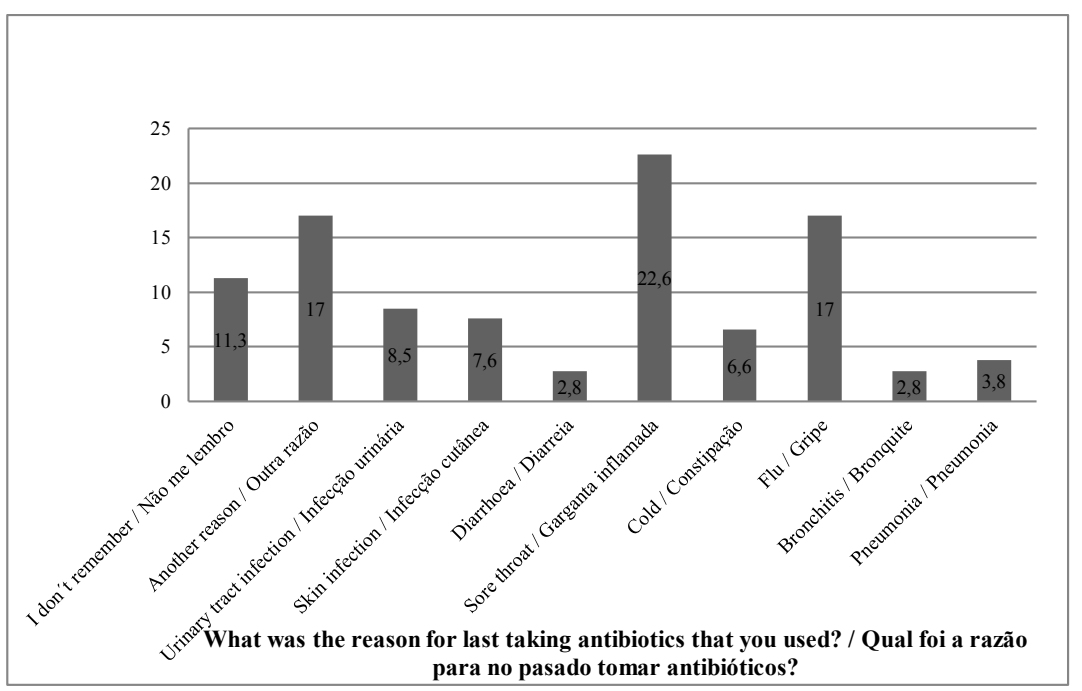

Figure 4 - Therapeutic indication for which the patients took antibiotic

Figura 4 - Indicação terapêutica para a qual os utentes tomaram antibiótico

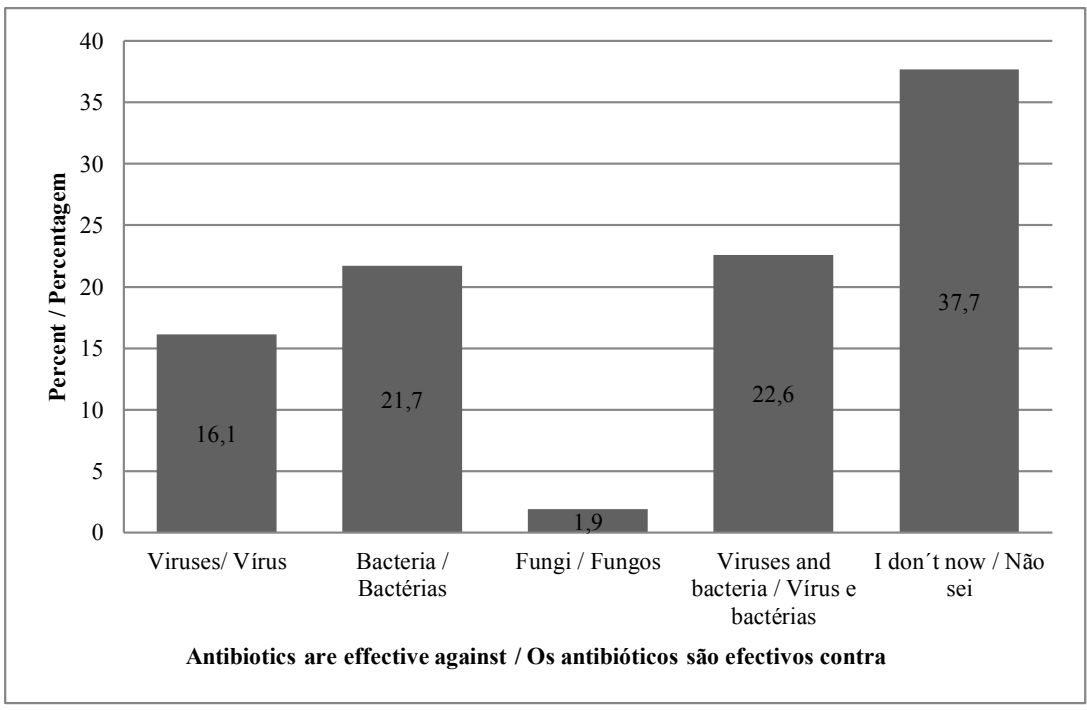

Figure 5 - Type of infections treated by antibiotics

Figura 5 - Tipo de infecções combatidas pelos antibióticos

the respondents during antibiotic treatment, $50 \%$ of respondents reported that they did not forget the administration of doses of antibiotics during the treatment. The remainder admitted to forgetting to take at least one dose within the recommended period. From these, $32.1 \%$ took the medication at another time and $17.9 \%$ did not get round to taking the forgotten dose.

Concerning the duration of the prescribed treatment, $69.8 \%$ of respondents declared that they fulfilled the required duration and $30.2 \%$ of subjects stated that they did not take the antibiotic until the end. This behavior results in inadequate treatment and promotes favorable conditions for bacteria to develop antibiotic resistance.
De acordo com a tabela 1, 64,2 \% dos inquiridos referiram que as bactérias causam frequentemente gripes e constipações. Embora seja obrigatória a apresentação de receita médica para a dispensa de antibiótico, 13,2 $\%$ dos utentes admitiram que já tentaram adquirir antibióticos sem receita médica. Relativamente aos comportamentos dos inquiridos durante o tratamento com antibiótico, $50 \%$ dos inquiridos referiram não se esquecerem da administração de tomas de antibiótico durante o tratamento. Dos que admitiram esquecer-se de alguma toma, $32,1 \%$ referiu que tomou o antibiótico quando se lembrou (não respeitando a frequência de administração) e 17,9 \% referiu que não o chegou a tomar. 
Table 1 - Other issues addressed in the survey

Tabela 1 - Outras questões abordadas no inquérito

\begin{tabular}{|c|c|c|}
\hline & $\begin{array}{c}\text { Yes / } \\
\text { Sim }(\%)\end{array}$ & $\begin{array}{c}\text { No / } \\
\text { Não }(\%)\end{array}$ \\
\hline $\begin{array}{l}\text { Bacteria often cause colds and flu. } \\
\text { As bactérias causam frequentemente gripes e constipações. }\end{array}$ & 64,1 & 35,9 \\
\hline $\begin{array}{l}\text { Have you ever tried to get antibiotics without a prescription? } \\
\text { Já alguma vez tentou adquirir antibióticos sem receita médica? }\end{array}$ & 13,2 & 86,8 \\
\hline $\begin{array}{l}\text { Have you ever forgotten to take antibiotic during treatment? } \\
\text { Já alguma vez se esqueceu de tomar antibiótico durante o tratamento? }\end{array}$ & 50 & 50 \\
\hline $\begin{array}{l}\text { When you feel better, the half treatment, stop taking the antibiotic. } \\
\text { Quando se sente melhor, a meio do tratamento, pára de tomar o antibiótico. }\end{array}$ & 30,2 & 69,8 \\
\hline $\begin{array}{l}\text { Have you ever taken higher dose of antibiotic than prescribed by your doctor? } \\
\text { Alguma vez tomou mais quantidade de antibiótico do que a indicada pelo seu médico? }\end{array}$ & 4,7 & 95,3 \\
\hline $\begin{array}{l}\text { Bacteria may become resistant to antibiotics. } \\
\text { As bactérias podem tornar-se resistentes aos antibióticos. }\end{array}$ & 81,1 & 18,9 \\
\hline
\end{tabular}

${ }^{[4]}$ In addition, $4.7 \%$ of respondents stated that they had taken a superior amount of the prescribed dose. Bacterial resistance to antibiotics is a current problem. 81.1 $\%$ of respondents recognized the existence of this problem, since they agree that bacteria may become resistant to antibiotics. However, $18.9 \%$ of respondents were not aware of this problem.

Since some respondents did not complete the treatment, it was important to ascertain what happens to the remaining antibiotic pills. As shown in Figure 6, 73.6 \% of respondents acted correctly, i.e., by depositing the leftover antibiotics in the pharmacy container Valormed._However, $11.3 \%$ of users left the remains in the bin and/or toilet, and $15.1 \%$ kept the rest at home for re-use on another occasion, which suggests that selfmedication takes place.

In $73.6 \%$ of cases where the patient was taking antibiotics but was not feeling better, the opted to consult the doctor. In $13.2 \%$ of cases, they consulted the pharmacist. $10.4 \%$ of users did nothing and $2.8 \%$ stopped taking the antibiotic.

To check whether there is a relationship between two variables, we tested the hypothesis of independence or the lack of association._Therefore, to relate two nominal variables, we used contingency tables and the chisquare test.
No que diz respeito à duração do tratamento prescrito, 69,8 $\%$ dos inquiridos tinha por hábito cumprir a duração do tratamento e 30,2 \% afirmaram não tomar o antibiótico até ao fim. Este comportamento resulta num tratamento incompleto que potencia o desenvolvimento de bactérias resistentes aos antibióticos. ${ }^{[4]}$ Além disso, 4,7\% dos inquiridos afirmaram já ter tomado uma quantidade superior à dose prescrita.

As resistências bacterianas aos antibióticos são uma problemática actual. Dos inquiridos, $81,1 \%$ reconheceram a existência deste problema, uma vez que concordaram que as bactérias podem tornar-se resistentes aos antibióticos. Contudo, $18,9 \%$ não tinham conhecimento deste problema.

Uma vez que alguns inquiridos não completaram o tratamento, tornou-se importante averiguar qual o destino que os utentes deram a essas sobras. Tal como mostra a figura 6, 73,6 $\%$ dos inquiridos afirmaram agir correctamente, ou seja, depositaram as sobras de antibiótico no contentor Valormed da sua farmácia. No entanto, $11,3 \%$ dos utentes depositaram as sobras no lixo e/ou sanita e 15,1\% guardaram o resto em casa para voltar a usar noutra situação, o que sugere automedicação.

Em 73,6 \% dos casos em que o utente se encontrava a tomar antibiótico e não se sentiu melhor, optou por consultar o médico. Em 13,2 \% dos casos, consultou o farmacêutico. 10,4 \% dos utentes não fez nada e 2,8 \% deixaram de tomar o antibiótico (figura 7).

Para se verificar se existe relação entre duas variáveis, a hipótese a ensaiar é a hipótese da independência ou da não existência de associação. Assim, para relacionar duas variáveis nominais recorreu-se à construção de tabelas de contingência e utilização do teste do Qui-quadrado. 
What do you do when leftover antibiotic after completion treatment? / O que faz quando sobra antibiótico após conclusão do tratamento

Eeep the rest at home for use in another situation / Guardo o resto em casa para voltar a usar em outra situação

$\square$ Deposit in trash or toilet / Deito no lixo ou sanita

n Give in the pharmacy for depositing in the container valormed / Entrego na farmácia para depositar no contentor valormed

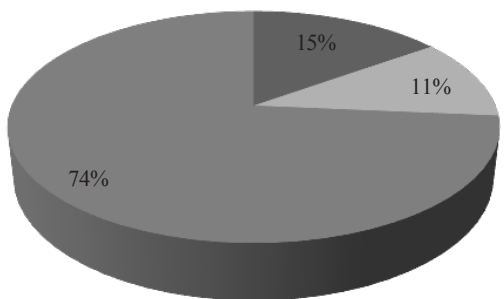

Figure 6 - Elimination mode of leftover antibiotics

Figura 6 - Modo de eliminação de sobras de antibiótico

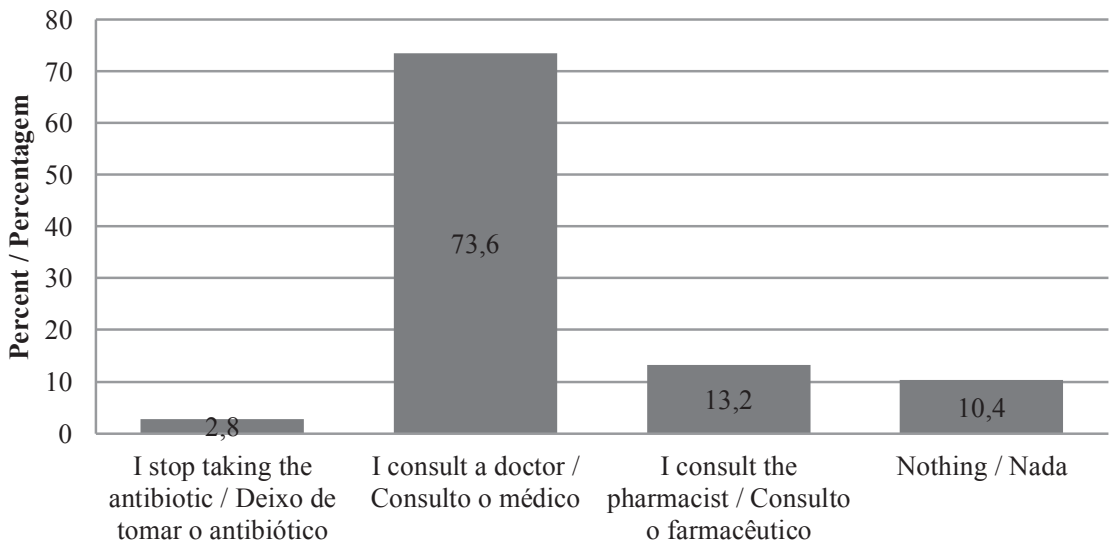

When you are taking antibiotics and not feeling better what do you do? / Quando se encontra a tomar antibiótico e não se sente melhor o que faz?

Figure 7 - Behavior when the patient no shows improvements during the treatment

Figura 7 - Comportamento do utente quando não apresenta melhorias durante o tratamento 
According to the results presented in Table 2, we verified the existence of a relationship between the variable knowledge of the type of infections treated by antibiotics and the socio-demographic variables age group $(p$-value $=0.001)$ and educational qualifications $(p$-value $=0.004)$. It was found that the age group 31-50 years old and respondents with college and higher education are those who had better knowledge about the type of infections treated by antibiotics.

Moreover, the majority of respondents who answered "I don't know" to this question are older than 66 years old and possess no educational qualifications or just the first grade._It was also found that the way leftover antibiotics are disposed of by respondents is related to the age group ( $p$-value $=0.022)$ and educational qualifications variables $(p$-value $=0.046)$._Contrary to what was expected, there was a greater tendency in respondents over 66 years old for depositing the remains of antibiotics in the Valormed container.
De acordo com os resultados apresentados na tabela 2, verificou-se a existência de relação entre a variável conhecimento do tipo de infecções combatidas por antibióticos e as variáveis sociodemográficas grupo etário ( $p$-value $=0,001)$ e nível de escolaridade $(p$-value $=0,004)$. Verificou-se que o grupo etário entre os 31 e 50 anos e o grupo dos inquiridos com o ensino secundário e superior são aqueles que têm maior conhecimento sobre o tipo de infecções combatidas pelos antibióticos.

Além disso, a maioria dos inquiridos que responderam "não sei" a esta questão têm mais de 66 anos e não têm escolaridade ou têm o $1^{\circ}$ ciclo. Também se verificou que o destino dado pelos inquiridos às sobras de antibiótico está relacionado com as variáveis grupo etário $(p$-value $=0,022)$ e nível de escolaridade $(p$-value $=0,046)$. Apesar do esperado, verificou-se uma maior tendência nos inquiridos com mais de 66

Table 2 - Relation between variables according to the chi-square test (variables associated with a significance level of $5 \%$ )

Tabela 2 - Relação entre variáveis de acordo com o teste do qui-quadrado (variáveis associadas para um nível de significância de 5\%)

\begin{tabular}{|l|r|}
\hline \multicolumn{1}{|c|}{ Variables / Variáveis } & \multicolumn{1}{|c|}{$\begin{array}{r}\text { Chi-square Test / } \\
\text { Teste Qui-quadrado } \\
\text { p-value }\end{array}$} \\
\hline $\begin{array}{l}\text { Knowledge of the type of infections treated by antibiotics \& Patient sex } \\
\text { Conhecimento do tipo de infecções combatidas por antibióticos \& Sexo do utente }\end{array}$ & 0,069 \\
\hline $\begin{array}{l}\text { Knowledge of the type of infections treated by antibiotics \& Age group } \\
\text { Conhecimento do tipo de infecções combatidas por antibióticos \& Grupo etário }\end{array}$ & 0,001 \\
\hline $\begin{array}{l}\text { Knowledge of the type of infections treated by antibiotics \& Educational qualifications } \\
\text { Conhecimento do tipo de infecções combatidas por antibióticos \& Nível de escolaridade }\end{array}$ & 0,022 \\
\hline $\begin{array}{l}\text { Elimination mode of leftover antibiotics \& Age group } \\
\text { Modo de eliminação de sobras de antibióticos \& Grupo etário }\end{array}$ & 0,046 \\
\hline $\begin{array}{l}\text { Elimination mode of leftover antibiotics \& Educational qualifications } \\
\text { Modo de eliminação de sobras de antibióticos \& Nível de escolaridade }\end{array}$ & 0,462 \\
\hline $\begin{array}{l}\text { Elimination mode of leftover antibiotics \& Patient sex } \\
\text { Modo de eliminação de sobras de antibióticos \& Sexo do utente }\end{array}$ & \\
\hline
\end{tabular}


Our results were consistent with results obtained in previous studies about the knowledge of the users regarding the use of antibiotics and the problem of bacterial resistance. ${ }^{[9,12,13,16-18]}$ In a similar study that assessed the level of knowledge about antibiotic treatment in Sweden, it was found that $19,1 \%$ of respondents agreed that antibiotics cure flu and 80,7 \% agreed that the inappropriate use of antibiotics might contribute to antibiotics resistance. ${ }^{[13]}$ Another study in the United States, by telephone interview, found that $12 \%$ of respondents had recently taken antibiotics and $27 \%$ of respondents believed that when suffering from flu, their health improved more rapidly while taking antibiotics. In this study, authors concluded that the demand for antibiotics might be affected by consumers' knowledge, attitudes and practices. ${ }^{[19]}$ Another Portuguese study, in the municipality of Vizela, found that $22,3 \%$ of respondents did not know what an antibiotic is. $13,1 \%$ said that an antibiotic is used in viral infections and just 7,9\% said an antibiotic is used in the treatment of bacterial infections. The same study also reported that the frequency of antibiotics intake is related to the variables of knowledge and use of antibiotics and gender. ${ }^{[18]}$

The results of this study enabled us to evaluate the level of knowledge of the population visiting the Pharmacy Campos Gomes. These data will be useful for better counseling about the importance of complying with the treatment duration and respecting the dose timings whenever the user receives a prescribed antibiotic. These results will also be useful in the evaluation of awareness in future actions related to these issues. Results are limited to a small population in Portugal and measures to prevent selection bias and control confounding were not previewed. Respondents were not questioned about why they did not complete the antibiotic treatment and whether they had ever been made aware of the rational use of antibiotics. Future studies should determine whether the awareness campaigns conducted managed to change attitudes towards the rational use of antibiotics.

\section{Conclusions}

The incorrect use of antibiotics is mainly conditioned by the use of antibiotics for non-bacterial infections, by failure to comply with dosage schedules, by failure to complete the total duration of treatment and incorrect storage and home waste disposal of the antibiotics. ${ }^{[16]}$ anos para depositarem as sobras de antibióticos no contentor Valormed.

De um modo geral, constatou-se que os resultados deste estudo estavam de acordo com resultados obtidos em estudos prévios, sobre os conhecimentos dos utentes relativamente ao consumo de antibióticos e à problemática da resistência bacteriana. ${ }^{[9,12,13,16-18]}$ Num estudo similar que avaliou o nível de conhecimento sobre o tratamento com antibióticos na Suécia, verificou-se que $19,1 \%$ dos inquiridos concordaram que os antibióticos curam gripes e $80,7 \%$ concordaram que o uso inadequado de antibióticos pode contribuir para a resistência aos antibióticos. ${ }^{[13]}$ Outro estudo realizado nos Estados Unidos da América sob a forma de entrevista telefónica concluiu que $12 \%$ dos inquiridos tinha tomado recentemente antibiótico e $27 \%$ dos entrevistados acreditavam que melhoraram mais rapidamente de uma gripe quando tomaram antibiótico. Neste estudo os autores concluíram que a demanda por antibióticos pode ser afectada pelo conhecimento dos consumidores, atitudes e práticas. ${ }^{[19]}$ Em outro estudo realizado em Portugal, no concelho de Vizela, verificou-se que $22,3 \%$ dos inquiridos não sabem o que é um antibiótico, $13,1 \%$ afirmaram que um antibiótico é usado em infecções virais e apenas 7,9\% afirmaram que um antibiótico é usado no tratamento de infecções bacterianas. O mesmo estudo também verificou que a frequência da toma de antibióticos está relacionada com as variáveis conhecimento e uso de antibióticos e género. ${ }^{[18]}$

Os resultados do presente estudo permitiram avaliar o conhecimento da população que frequenta a Farmácia Campos Gomes, facultando dados que serão úteis num melhor aconselhamento sobre a importância de cumprir a duração do tratamento e respeitos pelos horários das tomas, sempre que o utente apresente prescrição médica de um antibiótico. Estes resultados também serão úteis para uma possível avaliação desta sensibilização em futuras acções de intervenção nesta temática. Deste modo, os resultados deste estudo limitam-se a uma pequena população de Portugal e não foram tomadas medidas para prevenir o viés de selecção e para controlar o confundimento. Não se perguntou o motivo pelo qual o doente não tomou o antibiótico até ao fim, bem como se o inquirido alguma vez tinha sido sensibilizado para o uso racional de antibióticos. Futuros estudos deverão verificar se as acções de sensibilização realizadas até ao momento levaram a uma mudança de atitude no sentido do uso racional dos antibióticos.

\section{Conclusões}

O consumo incorrecto de antibióticos é devido principalmente à utilização de antibióticos em infecções de etiologia não bacteriana, ao incumprimento dos horários das tomas, ao incumprimento da duração total do tratamento, a erros de armazenamento e à eliminação 
These results revealed that a large number of respondents had some knowledge of bacterial resistance to antibiotics. However, there was some confusion about the concepts of "virus" and "bacteria" and their significance in relation to the prescription of antibiotics. Lack of knowledge was also demonstrated regarding the consequences of inappropriate use of antibiotics and regarding the belief that antibiotics could treat colds and flu. It was found that a large percentage of respondents did not know the reason for taking antibiotics.

The delivery of leaflets to users after answering the survey was welcomed as it clarified doubts about the topic. Thus, it is important to continue to alert the public and health professionals to the consequences of risky behaviors, often associated with the consumption of antibiotics and their inadequate and incorrect use. ${ }^{[16]}$

\section{Aknowledgemnts}

To all users of Pharmacy Campos Gomes who kindly responded to the survey.

\section{Conflict of Interest}

The authors declare that there is no financial or personal relationship that can be understood as representing a potential conflict of interest. dos resíduos dos antibióticos em meio domiciliário. ${ }^{[16]}$ Os resultados deste estudo demonstraram que um elevado número de inquiridos tem algum conhecimento sobre a existência de resistência bacteriana aos antibióticos. Contudo, verificou-se alguma confusão em torno dos termos "vírus" e "bactérias" e o significado destes relativamente à prescrição de antibióticos. Também se verificou uma falta de conhecimento dos utentes sobre as consequências do uso incorrecto de antibióticos e sobre a crença de que os antibióticos tratam gripes e constipações. Constatou-se que uma grande percentagem dos inquiridos não sabe para que efeito toma os antibióticos.

A entrega de folhetos informativos aos utentes após responderem ao inquérito foi bem aceite na medida em que existiu um esclarecimento de dúvidas personalizado sobre o tema abordado.

É importante continuar a alertar as populações e os profissionais de saúde para as consequências dos comportamentos de risco, associados ao consumo de antibióticos e à sua utilização inadequada e incorrecta. ${ }^{[16]}$

\section{Agradecimentos}

A todos os utentes da Farmácia Campos Gomes que gentilmente responderam ao inquérito.

\section{Conflitos de interesse}

Os autores declaram não existir qualquer relação de natureza financeira ou pessoal que possa ser entendida ou representar um potencial conflito de interesses. 


\section{References / Referências}

[1]. Hardman J, Limbird L. Goodman \& Gilman As Bases Farmacológicas da Terapêutica. 10 ed. Rio de Janeiro, MacGraw Hill, 2003

[2]. Murray RP, Rosenthal SK, Fauer M. Microbiologia médica: Antibióticos. 5 ed. Madrid: Elsevier, 2007.p.203-212.

[3]. Rodríguez A, Ortega M, Garzón L, et al. Tendencias de los fenotipos de resistencia bacteriana en hospitales públicos y privados de alta complejidad de Colombia. Revista Panam Salud Publica 2011; 30(6):627-33.

[4]. Duarte A. Resistência aos antibióticos - um problema de saúde pública. Mundo Farmacêutico 2005; 16(5): 72-77.

[5]. Dias M, Monteiro M, Menezes M. Antibiotics and bacterial resistance, old issues, new challenges. Clínica farmacológica. Lisboa: Hospital Cuf Descobertas; 2010.

[6]. European Surveillance of Antimicrobial Comsumption. |Web Page| Available at http://www.esac.ua.ac.be/main aspx? $=*$ ESAC2\&n $=50255$ (Accessed 22 March 2012).

[7]. Wannmacher L. Uso indiscriminado de antibióticos e resistência microbiana: uma guerra perdida?- Uso racional dos medicamentos. Brasília, 2004; 1(4).
[8]. Ruvinsky S, Mónaco A, Pérez G, et al. Motivos de la prescripción inadecuada de antibióticos en un hospital pediátrico de alta complejidad. Revista Panam Salud Publica 2011; 30(6):580-5.

[9]. Azevedo M, Pinheiro C, Yaphe J, et al. Portuguese student's knowledge of antibiotics: a cross-sectional study of secondary school and university students in Braga. BMC Public Health 2009; 9:359.

[10]. Cals JWL, Boumans D, Lardinois R, et al. Public beliefs on antibiotics and respiratory tract infections: an internet-based questionnaire study. British Journal of General Practice 2007; 57(545):942-47.

[11]. Deschepper R, Grigoryan L, Lundborg C, et al. Are cultural dimensions relevant for explaining cross-national differences in antibiotic use in Europe?. BMC Health Services Research 2008; 8:123.

[12]. McNulty C, Boyle P, Nichols T, et al. Don`t wear me out - the public's knowledge of and attitudes to antibiotic use. Journal of Antimicrobial Chemotherapy 2007; 59: 727-738.

[13]. Malin A, Aso V, Johanna B, et al. A Survey of public knowledge and awareness related to antibiotic use and resistance in Sweden. Journal of Antimicrobial Chemotherapy. Sweden, 2010
[14]. Ministério da Saúde, Direcção Geral da Saúde. Programa Nacional de Prevenção das resistências aos antimicrobianos. Lisboa: Ministério da Saúde, 2009.

[15]. Ministério da Saúde. Despacho $\mathrm{n}^{0}$ 20729/2008. Diário da República: $2^{\mathrm{a}}$ série, $\mathrm{n}^{\circ} 152,7$ de Agosto de 2008.

[16]. Alert Life Sciences Computing. |Web Page| Available at http://www.alert-online.com/ pt/news/health-portal/portugueses-sao-dosmenos-informados-sobre-antibioticos (Accessed 17 June 2013).

[17]. Widayati A, Suryawatis S, Crespigny C, et al. Knowledge and beliefs about antibiotics among people in Yogyakarta City Indonesia: a cross sectional population-based survey. Antimicrbial resistance infection control 2012; 1:38.

[18]. Ribeiro M, Pinto I, Pedrosa C. Comportamento da população do concelho de Vizela no consumo de antibióticos. Revista portuguesa de saúde pública 2009; 27(2):57-70.

[19]. Vanden J, Marcus R, Hadler J, et al. Consumer Attitudes and Use of Antibiotics. Emerging Infectious Diseases 2003; 9(9):1128-35 